
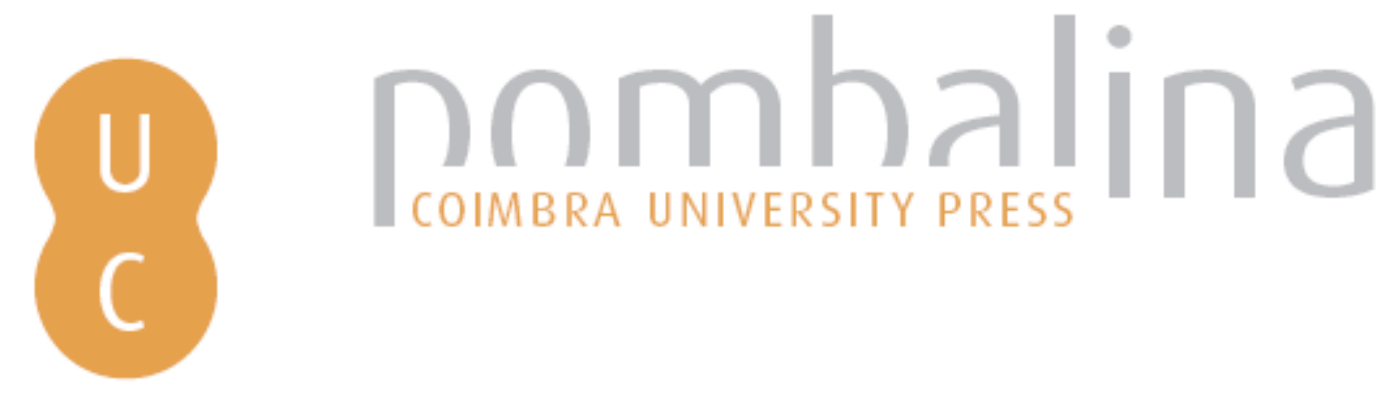

\title{
No palco e nos bastidores do poder local
}

Autor(es): $\quad$ Coelho, Maria Helena da Cruz

Publicado por: Imprensa da Universidade de Coimbra; CEFA

URL

persistente: URI:http://hdl.handle.net/10316.2/32453

DOI: $\quad$ DOI:http://dx.doi.org/10.14195/978-989-26-0439-8_2

Accessed : $\quad$ 26-Apr-2023 00:37:32

A navegação consulta e descarregamento dos títulos inseridos nas Bibliotecas Digitais UC Digitalis, UC Pombalina e UC Impactum, pressupõem a aceitação plena e sem reservas dos Termos e Condições de Uso destas Bibliotecas Digitais, disponíveis em https://digitalis.uc.pt/pt-pt/termos.

Conforme exposto nos referidos Termos e Condições de Uso, o descarregamento de títulos de acesso restrito requer uma licença válida de autorização devendo o utilizador aceder ao(s) documento(s) a partir de um endereço de IP da instituição detentora da supramencionada licença.

Ao utilizador é apenas permitido o descarregamento para uso pessoal, pelo que o emprego do(s) título(s) descarregado(s) para outro fim, designadamente comercial, carece de autorização do respetivo autor ou editor da obra.

Na medida em que todas as obras da UC Digitalis se encontram protegidas pelo Código do Direito de Autor e Direitos Conexos e demais legislação aplicável, toda a cópia, parcial ou total, deste documento, nos casos em que é legalmente admitida, deverá conter ou fazer-se acompanhar por este aviso.

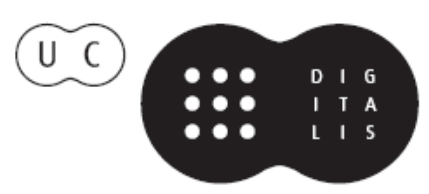


FERNANDO TAVEIRA DA FONSECA

\section{Coordenação}

O poder local em tempo de

Globalização

uma história

e um futuro

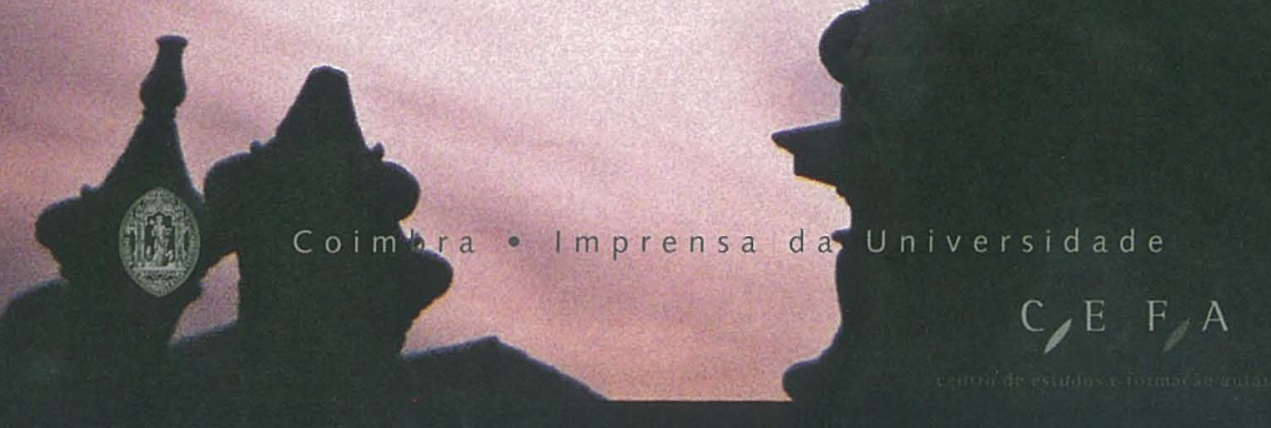


(Página deixada propositadamente em branco) 


\section{FERNANDO TAVEIRA DA FONSECA}

Coordenação

$\mathrm{O}$

poder local

em tempo

de

Globalização

uma história

e um futuro

Coimbra - Imprensa da Universidade

$C, E, F / A$ 
COORDENAÇÃo EDITORIAL

Imprensa da Universidade de Coimbra

CONCEPÇÃo GRÁfICA

António Barros

PAGINAÇÃo

António Resende

[Universidade de Coimbra]

EXECUÇÃo GRÁFICA

G.C. - Gráfica de Coimbra, Lda.

Palheira - Assafarge - Apart. 3068

3001-453 Coimbra Codex

\section{ISBN}

972-8704-32-1 (IUC)

972-8809-11-5 (CEFA)

DEPÓSITO LEGAL

229953/05

(c) JUNHO 2005, IMPRENSA DA UNIVERSIDADE DE COIMBRA 


\section{Maria Helena da Cruz Coelho \\ Faculdade de Letras da Universidade de Coimbra}

\section{NO PALCO E NOS BASTIDORES DO PODER LOCAL}

Conheçamos os palcos do poder local. Em mais de seis dezenas de concelhos que, por ordem de D. Fernando, se reuniram ao longo do mês de Julho de 1383 para escolherem os procuradores que, devidamente creditados, iriam às Cortes a terem lugar em Santarém, no mês de Agosto, para jurarem D. Beatriz, filha do monarca, e seu marido, D. João I, rei de Castela, como herdeiros da Coroa portuguesa. ${ }^{(1)}$

Perante nós apresentam-se espaços religiosos de igrejas e mosteiros, espaços urbanos, construídos e abertos, e espaços ruralizados. Acerquemo-nos.

A proximidade dos lugares sagrados busca-se em reuniões junto de ermidas, atrás de igrejas, no seu alpendre ou no seu adro. Mas, num espírito de grande intimidade entre o civil e o religioso, caminha-se do exterior para o seu interior, juntando-se a vereação no claustro e cabido de igrejas e mosteiros.

Em cenários urbanos construídos, destacam-se os paços do concelho, da audiência ou da relação, ou o sobrado da casa do concelho. Mais esporadicamente caminha-se até à torre do concelho ou até aos paços dentro do castelo. Mas a cidade é também espaço público e aberto, que os homens procuram para se reunir. E no eixo das espacialidades agregadoras encontram-se os homens na maior praça da vila, na praça do açougue, ou ainda por dentro delas em especiais recantos de todos conhecidos, como ante as casas de um juiz da vila ou de um mercador.

Marcos simbólicos de passagem ou de interdição e resguardo, do de dentro face ao de fora, são as portas. Não poucas vezes à porta da casa da audiência, ou às portas do castelo se congrega a assembleia vicinal. Para noutros lugares se arrimarem os vizinhos a marcos referentes da convivialidade do quotidiano, como uma cisterna

(1) Tomamos como base para este estudo as informações das procurações dos concelhos recolhidas na obra Cortes Portuguesas. Reinado de D. Fernando (1367-1383), vol. II, (1383), ed. preparada por A. H. de Oliveira Marques e João Paulo Salvado, Lisboa, JNICT, 1993. Ao todo, referimo-nos a 64 concelhos, aí se incluindo um julgado (Lanhoso) e um couto (Treixedo, do mosteiro de Lorvão). Diga-se ainda que os concelhos de Penela e Miranda se associaram para escolherem procuradores às Cortes. Casos à parte são Alcobaça e Idanha-a Nova em que foram, respectivamente, o abade e o comendador que instituíram os seus procuradores para irem às Cortes. 
ou um celeiro, evocação já de um rural entressachado no urbano. E essa ruralidade do aro ou termo concelhio, traduzida num campo, num chão, num outeiro, num pombal, numa quinta, é mesmo procurada em vilas outras.

Preencheram-se estes palcos com os actores do teatro do poder constituído. São eles comummente os juízes, os vereadores e o procurador do concelho. (2) Para além dos homens bons que circulam pela vereação. Um escasso número de actores, no geral entre uma e duas dezenas. ${ }^{(3)}$

Os magistrados judiciais encontram-se sempre presentes, à excepção de um caso, ${ }^{(4)}$ oscilando o seu número entre um e três, ${ }^{(5)}$ estando a justiça, na maioria dos concelhos, entregue a dois juízes. Juízes ditos alvazis em áreas de forte influência muçulmana, como Leiria, Santarém, Lisboa, Cascais e Tavira, enquanto noutros lugares nortenhos, que se modelaram pelo normativo do foral salamantino, perduraria a designação de alcaldes. (6) Nas três mais importantes cidades capitais do reino, Lisboa, Santarém e Évora, deparamos com a especialização da magistratura judicial, afectando-se um juiz ao cível e dois aos crime, contando ainda Lisboa com dois alvazis dos ovençais. Esta especialização exige competência. Logo, o alvazil lisboeta do cível é bacharel em Leis, como também o é um dos do crime, sendo o outro um escudeiro. Um letrado, desta vez um escolar em Leis, assume ainda as funções judiciais em Leiria. São escassíssimas nesta fonte, como em todas as demais, as precisões da categoria social dos oficiais. Por isso mesmo preciosas. Encontramos prioritariamente escudeiros a desempenhar este cargo, para além de um vassalo do rei, um cavaleiro e um mercador. ${ }^{(7)}$

Logo a seguir aos juízes, surgem, por ordem de grandeza, os vereadores eleitos. Aqui quase se equiparam os concelhos administrados por dois ou três vereadores,

\footnotetext{
(2) Para uma análise do aparelho burocrático concelhio nestes séculos, leia-se Maria Helena da Cruz Coelho e Joaquim Romero Magalhães, O Poder Concelhio das origens às Cortes Constituintes. Notas de História Social, Coimbra, CEFA, 1986.

(3) Para além dos oficiais, estão abaixo da dezena os homens bons referidos para Castelo Mendo (três), Monsanto (quatro), Lourinhã (cinco), Pinhel e Ponte de Lima (seis), Crato (sete), Covilhã (oito). Entre a dezena e a vintena contam-se os homens bons em vereação nos concelhos de Cascais, Évora, Faro, Olivença, Silves (dez), Montemor-o-Velho, Torres Novas (onze), Guarda, Pombal (doze), Avis (treze), Alcácer do Sal (catorze), Setúbal (dezasseis), Estremoz, Tomar (dezoito), Braga (vinte). Mais de vinte homens bons estiveram presentes apenas em cinco concelhos: Atouguia, Chaves (vinte e um), Castelo Bom (vinte e três), Alandroal (vintè e quatro) e Vila Viçosa (trinta e um).

(4) À excepção de Numão.

(5) Em $60 \%$ dos concelhos existem dois juízes e em 17\% um. São apenas seis concelhos - Chaves, Évora, Faro, Lisboa, Pinhel e Santarém - que dispõem de três juízes.

(6) E julgamos haver lapso de leitura na referida obra, não sendo alcaide, mas sim alcalde que se deve ler para Caminha, Viana do Lima e Vila Nova de Cerveira.

(7) Em Alcácer do Sal, um dos juízes é escudeiro e outro mercador. Em Leiria, um é vassalo do rei e outro, como dissemos, escolar em Leis. O alvazil do cível em Santarém é cavaleiro. O alvazil do crime em Lisboa é escudeiro. E há juizes escudeiros em Serpa, Setúbal, Soure e Vila Viçosa.
} 
ainda que também os haja com um ou quatro. ${ }^{(8)}$ A precisar o seu estatuto social, magras notas nos chegam - um escudeiro é vereador em Leiria, um mercador é-o em Santarém e um ferreiro desempenha o cargo em Castelo Mendo. Acresce que, na falta dos vereadores eleitos, já deparamos com a figura dos vereadores substitutos, assim acontecendo a um de Castelo Bom, aos dois de Monforte de Rio Livre e aos três de Santarém, mecanismo que ao longo dos tempos veio a permitir um tirocínio dos mais jovens no desempenho de ofícios, abrindo-lhes em seguida o caminho para a sua inclusão no grupo dos elegíveis.

No último lugar do oficialato concelhio, mas sempre presente, posiciona-se o procurador que tem o encargo de representar no interior ou exterior toda a comunidade. Esporadicamente ocorre a presença de algum outro oficial concelhio, como um saião em Setúbal, um escrivão da câmara ou concelho em Évora e Vila Viçosa, o chanceler do concelho em Tavira, o alferes da sina (bandeira) do concelho em Castelo Rodrigo ou os procuradores do número em Santarém, o que nos corrobora a diversidade das funções municipais.

Mas esta foi uma assembleia extarordinária dos concelhos, exigida por ordem régia. Daí que as procurações insistam que a mesma havia sido convocada mediante pregão, especificando muitas vezes até os nomes dos pregoeiros ou porteiros que a anunciaram, dando assim entrada a mais dois oficiais executivos dos concelhos.

Os delegados dos mandados régios foram, como seria de esperar, os corregedores. E assim os vemos circularem. O corregedor de Entre Douro e Minho, Afonso Martins Alvernaz, estava no Porto a 5 de Julho, em Guimarães a 9 e em Braga a 12. O corregedor da Beira, Diogo Gil, encontrava-se na Covilhã a 6 de Julho, na Guarda a 7, em Trancoso a 10 e em Castelo Rodrigo a 16. O corregedor da Estremadura, Geraldo Anes, estanciava em Óbidos a 5 de Julho, em Soure a 10, em Montemor-o-Velho a 11, em Penela a 13 e em Santarém a 21. Finalmente o corregedor do Algarve, Vasco Gil, marcava presença a 14 de Julho em Albufeira, a 18 em Faro e a 19 em Tavira.

Chegados às localidades, e a tomarmos como paradigmáticas as notícias para o Porto, mandavam convocar os vizinhos do concelho pelos pregoeiros, a fim de tomarem conhecimento de uma carta régia.(9) Já em reunião e lida a carta régia, escrita em Almada, a 26 de Junho, e validada com o selo da puridade, que creditava o

(8) Anote-se que não encontramos referência expressa a vereadores em Braga e Monsanto. Nos demais, em 38,5\% dos concelhos há dois vereadores, em 43,15\% há três, em Tomar deparamos apenas com um, e em Caminha, Elvas, Évora, Guarda, Montemor-o-velho, Sertã e Sintra assinalam-se quatro.

(9) Sobre o circuito das comunicações nos municípios, leia-se Maria Helena da Cruz Coelho, «A rede de comunicações concelhias nos séculos XIV e XV», in As Comunicações na Idade Média, coord. de Maria Helena da Cruz Coelho, Lisboa, Fundação Portuguesa das Comunicações, 2002, pp. 64-101. 
corregedor como transmissor da vontade real, este oficial determinava que o conceIho escolhesse dois procuradores e os mandatasse com uma carta de procuração, escrita de acordo com uma "Nõta que logo o dicto Corregedor mostrou e lẽeo» e que se transcreve. O objectivo era comparecerem nas Cortes de Santarém, a reunir em Agosto, a fim de jurarem os herdeiros do trono. ${ }^{(10)} \mathrm{E}$ quando o corregedor não estava nas localidades no dia da reunião, sabemos que por elas teria passado, como se regista para Castelo Bom, onde o corregedor da Beira, Diogo Gil, deixara «hũu trallado escripto em papel», pelo qual o tabelião diz ter redigido a procuração.

De uma outra natureza, um vez que se trata de um oficial régio fixo no concelho, encontramos em algumas assembleias os alcaides dos castelos, muito em particular nas cidades e vilas com uma real importância militar e geo-estratégica. (11)

Como caso singular, há ainda a assinalar a presença de um juiz de fora em Elvas, única vila em que não se encontram os juízes eleitos, mas apenas um oficial da justiça nomeado pelo rei, certamente porque o monarca queria assegurar a fidelidade às suas ordens deste vital centro fronteiriço.

Acresce que, sobretudo quando as sedes de concelho coincidiam com as cabeças dos almoxarifados, não poucas vezes deparamos com os almoxarifes presentes nas reuniões camarárias, o que acontece em sete concelhos. ${ }^{(12)}$

Parece legítimo concluir que nestas assembleias, que se reúnem com o objectivo exclusivo de escolher procuradores às Cortes de 1383, o peso dos oficiais régios foi pouco significativo, cabendo o ónus de tal decisão aos mandantes e homens bons dos diversos concelhos. Mas qual a composição social dessa elite de mando? Valorizemos as parcas informações que possuímos.

Moura, para além de nomear as autoridades concelhias e alguns homens bons, acrescenta que estiveram presentes «todollos outros omeens boos do concelho... asy caualejros come pioes e bestejros», clivagem social que passa ainda pela hierarquização militar que o período de guerra e recrutamento de homens reavivava.

A vivência do económico e social desvenda-se quando, em alguns centros concelhios, nos são referidos nobres, mercadores, homens da escrita e letrados,

(10) O mesmo se afirma para Faro, parecendo no entanto que a carta régia de creditação do corregedor do Algarve estava datada de 15 de Junho. Acresce que se afirma que as Cortes deviam iniciar-se a 1 de Agosto.

(11) Assim em Caminha, Cascais, Castelo Rodrigo, Crato, Elvas, Faro, Guimarães, Monção, Montemor-o-Velho (estas duas vilas com dois alcaides), Óbidos (presente o alcaide e seu escudeiro), Pombal, Santarém, Tavira e Vila Viçosa (onde se encontra o alcaide mor e o alcaide pequeno). Referese ainda em Atouguia um homem que foi alcaide.

(12) São eles Cascais, Faro, Guarda, Guimarães, Moura (onde o almoxarife é também dito alcaide dos mouros), Olivença e Setúbal. Cita-se ainda um homem, que fora almoxarife, em Chaves e Santarém 
mesteirais e homens do termo na constituição da assembleia reunida. ${ }^{(13)}$ A feição aristocrática de muitos centros urbanos manifesta-se pela presença de escudeiros, vassalos do rei e cavaleiros, estes em menor número, na vereação. ${ }^{(14)}$ Na maior parte dos casos trata-se, manifestamente, de uma pequena nobreza que, como já tem sido repetido, deve resultar da miscegenação de membros de famílias nobres com elementos da aristocracia vilã, protagonizando por vezes certos cargos, mormente o de juiz, como vimos.

Os mercadores são-nos assinalados menos para os grandes centros ou localidades próximas e litorâneas, ${ }^{(15)}$ como seria de esperar, mas mais para localidades raianas e alentejanas, ${ }^{(16)}$ ainda que os muitos nomes de homens bons sem especificação de profissão ou categoria social encubram por certo este grupo de maiores ou médios comerciantes, que ultrapassaram as interdições sócio-religiosas que durante alguns séculos pesaram sobre a mercancia e o dinheiro e se guindaram a uma relevante e prestigiada posição social. ${ }^{(17)}$ Acresce que, em Lisboa, a cidade das «desvairadas gentes» se assinala ainda a presença de um cambiador.

Com muito mais peso se intrometem na vereação os homens que detêm o poder do escrito e mesmo sobre os escritos de âmbito administrativo e urbano. Referimo-nos, obviamente, aos tabeliães. Em todas estas vilas, eles tiveram de ser convocados para escreverem as cartas de procuração dos referidos procuradores concelhios às Cortes. Todavia, em muitas localidades, surgem como testemunhas desse acto ou, o que é ainda mais significativo, figuram entre os homens bons da vereação.

$\mathrm{Na}$ verdade, parece-nos ser ainda um aspecto a sopesar devidamente esta presença de homens que dominam a escrita no corpo dos que dirigem um concelho. Eles são uma força muito significativa em sociedades em que predomina a iliteracia.

(13) Nas testemunhas das procurações figuram por vezes clérigos, ditos em alguns casos vigários, priores e abades, nas vilas de Castelo Bom, Estremoz, Mértola, Odemira, Olivença, Penedono, Penela e Viana do Lima.

(14) Escudeiros surgem-nos em Alcácer do Sal (dois), Atouguia, Tavira, Estremoz, Guimarães, Monforte de Rio Livre, Montemor-o-Velho, Trancoso, Óbidos, Santarém (dois), e Vila Viçosa (três); vassalos do rei em Chaves (dois) e Crato; cavaleiros em Crato (dois), Estremoz, Moura (dois vassalos do rei que são escudeiros), e em Óbidos quatro vassalos de um conde.

(15) Conta-se um mercador em Ponte de Lima, Santarém, Soure e Óbidos

(16) Tal o caso de Castelo Bom, Chaves (aqui três), Crato, Évora, Olivença, um tendeiro em Vila Viçosa, e um marceiro em Chaves.

(17) Para um enquadramento geral desta temática, leia-se Jacques Le Goff, «Profissões lícitas e profissões ilícitas no Ocidente medieval», in Para um Novo Conceito de Idade Média. Tempo, Trabalho e Cultura no Ocidente, trad. port., Lisboa, Editorial Estampa, 1980, pp. 85-99, e Mercadores e Banqueiros na Idade Média, trad. port., Lisboa, Gradiva, 1982, e Aron Ja. Gurevic, "O Mercador», in O Homem Medieval, trad. port., Lisboa, Editorial Presença, 1989, pp. 165-189. Para a análise do caso português, e mais concretamente dos mercadores de Coimbra, veja-se Maria Helena da Cruz Coelho, «Homens e Negócios», in Ócio e Negócio, Coimbra, Inatel, 1998, pp.127-202. 
Crescendo, nas centúrias de Trezentos e Quatrocentos, as exigências de firmar pelo escrito actos de posse e contratos de bens, empréstimos de dinheiro ou bens móveis, delegar poderes de representação em procurações, estipular vontades pessoais em vida ou mesmo para além da morte, o recurso aos tabeliães torna-se quotidiano e repetido. Logo, estes especialistas do saber escrever ganham poder económico e alcançam mesmo prestígio social. Possuem a capacidade de conhecer individualmente os movimentos económicos de muitos vizinhos, seja a sua riqueza atestada em compras, exploração de prédios, arrematação de rendas ou créditos, seja as suas fragilidades anotadas em dívidas, empréstimos ou venda de haveres, ou até as disposições e quereres pessoais mais íntimos, testemunhados em cartas de dote ou arras e testamentos. Mais amplamente, conhecem os negócios das vilas e cidades e a sua escrituração colectiva, estando alguns deles mesmo ao serviço dos concelhos e todos se conhecendo e, sem dúvida, permutando informações.

Adquirem por isso, para além de um peso económico que lhes advém do exercício de um ofício cada vez mais requisitado, o qual thes vai mesmo permitir angariar disponibilidades monetárias para investir na terra e em manipulação de rendas, um prestígio social, dada a sua imprescindibilidade e omnipresença, que os leva a privar com os grandes e poderosos, assimilando então os seus valores e códigos comportamentais e mesmo unindo-se-lhes por estratégias matrimoniais ou de mando.(18) E é assim que vemos tabeliães a integrar expressamente o corpo dos homens bons de lugares tão distintos como o Alandroal, Chaves (aqui contando-se cinco), Guarda, Monforte de Rio Livre, Monsanto, Montemor-o-Velho, Ponte de Lima, Santarém, Sesimbra, Setúbal, Tomar, a par de um escrivão em Faro, podendo este rol aumentar grandemente se lhe acrescentássemos as localidades onde os tabeliães figuram como testemunhas. ${ }^{(19)}$

Não será ousado afirmar que o poder se permeabiliza ao saber. Na realidade, verificamos também que, nesta década de 80 , alguns letrados, por certo formados

(18) Sobre os tabeliães nestes séculos, consulte-se Maria Helena da Cruz Coelho, «Os Tabeliães em Portugal. Perfil Profissional e Sócio-Económico», in Estudos de Diplomática Portuguesa, Lisboa, Edições Colibri-FLUC, 2001, pp. 93-137, e Bernardo Sá Nogueira, «Tabelionado e elites urbanas no Portugal Ducentista (1212-1279)», in Elites e Redes Clientelares na Idade Média. Problemas Metodológicos, ed de Filipe Themudo Barata, Lisboa, Edições Colibri. CIDEHUS-UE, 2001, pp.211220.

(19) O que acontece em Abrantes, Albufeira, Alcácer do Sal (quatro), Arronches (cinco), Atouguia, Avis (três), Braga (dois), Caminha (três), Cascais, Castelo Mendo, Castelo Rodrigo (quatro), Chaves (três), Covilhã, Elvas, Estremoz, Évora (um homem que foi tabelião), Guarda (um homem que foi tabelião), Guimarães, Lanhoso, Leiria, Lourinhã, Melgaço, Monção, Monsanto, Montemor-o-Velho, Numão, Odemira, Pinhel, Porto, Sabugal, Serpa (cinco), Sesimbra, Setúbal (dois), Trancoso, Viana do Lima (dois), Vila Nova de Cerveira (três), Vila Viçosa. 
no Estudo Geral do país, marcam já presença na esfera do poder local. Seria um tirocínio para aqueles que, com os primeiros graus universitários, almejariam obter, com mais aprofundados estudos, um ofício no paralelo da burocracia da corte. Assim deparamos com um bacharel em Leis na vereação de Atouguia, um escolar em Tomar, um escolar que era juiz em Leiria, bacharéis em Leis que eram alvazis do cível e crime em Lisboa e um mestre em Vila Viçosa. Mais relevante será termos presente que em Santarém um tabelião é dito Mestre Lopo, como também o tabelião do rei em Tomar era Mestre Gonçalo, que tinha escrivão próprio. Se a maioria dos homens da escrita se formavam nas escolas urbanas e adquiriam os seus conhecimentos específicos aprendendo o ofício junto de outros tabeliães, parece que alguns se guindaram a um mais aprofundado saber, cursando talvez mesmo a Universidade. E, ainda que por ora o nosso conhecimento seja escasso, este conjunto de letrados e legistas, actuando nos concelhos, levar-nos-á a redimensionar o pensamento de Marcello Caetano, ao afirmar que a Universidade de Lisboa foi o «centro intelectual da revolução de 1383-85",(20) projectando-a não só a nível do poder central mas também do poder local. ${ }^{(21)}$

Aliás, os concelhos revêem-se na sua feição aristocrática, letrada ou de mando para se fazerem representar nesse palco maior de jogo cénico que são as Cortes. Só estes protagonistas mais creditados poderiam dignamente e com discernimento falar, em nome dos municípios, ao lado de nobres e clérigos, perante o monarca e seu oficialato. Em cerca de metade dos municípios que instituíram procuradores às Cortes de Santarém de 1383 possuímos algumas notas sobre a sua posição. No geral, o número de procuradores por concelho foi de dois, como era comum, mas há casos de só um ter sido escolhido ou três, quatro e estranhamente mesmo dez. Averiguamos que, em treze municípios, alguns ou todos os seus procuradores foram escudeiros, muitas vezes ditos vassalos e criados do rei. Dez centros urbanos fizeram-se representar por oficiais eleitos, no geral juízes - em três casos também escudeiros - mas ainda vereadores e procuradores do concelho ou julgado. Em seis concelhos — Arronches, Crato, Monforte de Rio Livre, Pombal, Silves, Viana do Lima - temos a presença de tabeliães como procuradores. Curiosamente, em Viana do Lima, foram mesmo escolhidos dois tabeliães para o efeito, mas porque um deles morava fora da vila, e o corregedor ordenara que os procuradores deviam ser do lugar, foi substituí-

(20) Marcello Caetano, A Crise Nacional de 1383-1385. Subsídios para o seu estudo, Lisboa - São Paulo, Editorial Verbo, 1985, p. 150.

(21) Curiosamente assinala-se, em 1368, um juiz de fora em Coimbra, doutor em ambos os direitos (doctor in utroque iure), justamente no período em que a Universidade se encontrava na cidade (António Manuel Hespanha, História das Instiruições. Épocas Medieval e Moderna, Coimbra, Livraria Almedina, 1982, p. 432). 
do por um vizinho, cuja categoria social se não especifica. Só excepcionalmente há oficiais régios, ${ }^{(22)}$ mercadores ${ }^{(23)}$ ou homens do termo ${ }^{(24)}$ entre os procuradores concelhios. O poder local faz-se, pois, representar em Cortes por aqueles que mais se aproximam dos homens nobres, cultos e com poder que eram os cortesãos. Por isso, alguns anos mais tarde, estando já consumada essa assimilação à aristocracia, os vereadores de Évora querem pintar as suas armas e divisas na casa da câmara, honraria que $D$. Manuel, defensor de um poder régio centralizante, em acto e representação, não lhes permitiu. (25)

Anote-se, porém, que um dos procuradores de Alcácer do Sal, a ombrear com um escudeiro, é dito vaqueiro. No ar paira a interrogação - trata-se de um criador de gado ou de um homem do povo, um assalariado? Neste último caso, estaríamos perante uma situação excepcional. Esporadicamente, na composição social das vereações concelhias, foram surgindo homens dos mesteres como sapateiros, ${ }^{(26)}$ tanoeiros, ${ }^{(27)}$ alfaiates, ${ }^{(28)}$ ferreiros ${ }^{(29)}$ ou pedreiros ${ }^{(30)}$ em Albufeira, Atouguia, Braga, Castelo Bom e Chaves, que ainda acrescentam o seu número entre as testemunhas, ${ }^{(31)}$ ou até homens do termo, certamente mais identificados com o amanho da terra, em alguns centros interiores e raianos. ${ }^{(32)} E$ a força do trabalho a impor-se, ainda que individual e excepcionalmente, por entre o grupo aristocratizado, possidente e mercantil dos mandantes. A sua força, neste final de Trezentos, é inegável. Mas o seu protagonismo e teatro de acção serão outros.

De facto, a teatralidade medieval não conhece apenas um só espaço de representação, mas cenários múltiplos au até simultâneos, que combinam horizontal e verticalmente as suas peças. Do mesmo modo, o contacto entre actores e público é

(22) Um alcaide no Crato e um homem que fora almoxarife em Atouguia.

(23) Entre os três procuradores escolhidos por Braga, um é escudeiro e dois são mercadores. Também um dos quatro procuradores de Caminha é mercador. Santarém escolhe um escudeiro e um mercador como seus procuradores.

(24) São dois homens do termo que representam a vila de Cascais e um homem do termo que é procurador do couto de Treixede, pertença do mosteiro de Lorvão

(25) Carta régia de D. Manuel para o juiz de Évora, de 1501 (Gabriel Pereira, Documentos Históricos da Cidade de Évora, ed. fac-similada, Lisboa, Imprensa Nacional - Casa da Moeda, 1998, p. 499).

(26) Na vereação em Albufeira, Atouguia, Castelo Bom e Chaves e entre as testemunhas em Odemira, Pinhel e Vila Viçosa.

(27) Referem-se três em Atouguia.

(28) Na vereação em Braga e, como testemunhas, em Olivença, Lourinhã e Ponte Lima (em cada uma das duas últimas vilas dois alfaiates).

(29) Em Castelo Bom e Chaves.

(30) Na vereação em Chaves e entre as testemunhas de Viana do Lima (dois).

(31) Figuram como testemunhas um correeiro em Évora, ourives em Évora e Óbidos, para além de carniceiros em Penela e Viana do Lima e um marinheiro em Viana do Lima.

(32) Tal o caso de Castelo Bom, Castelo Rodrigo, Chaves e Numão. Também na reunião de Cascais estão presentes os vintaneiros do termo. 
muito estreito, frequentemente interagindo, a ponto de quase se confundirem os mundos do representado e do vivido. ${ }^{(33)}$

Logo, enquanto o poder institucionalizado assim era desempenhado por aqueles actores principais, outros palcos se abriam e novos protagonistas entravam em acção no jogo do mandar e ser mandado. Se estas Cortes de 1383 representam o epílogo político de toda a acção fernandina, as incidências do seu governo tinham já um longo passado. A instabilidade económica, a desvalorização da moeda, as crises frumentárias, as guerras com Castela e acontecimentos mais mediáticos, como o casamento indesejado do monarca, provocaram levantamentos populares.

Emergindo de um cenário quotidiano de pesado trabalho e opressiva carga fiscal, os mandados fizeram ouvir a sua voz. A união do monarca com Leonor Teles, anunciada em 1371 e concretizada em 1372, foi o detonador da revolta. Mas a má vontade, se não mesmo o ódio do povo contra Leonor, servia apenas para incendiar os ânimos e desencadear os actos. Porque o movimento colectivo de protesto tinha raízes profundas na crise económica e social que se abatia sobre o povo.(34) A liderá-lo estão muitas vezes mesteirais, homens que, com duro esforço, transformavam a matéria--prima em obra acabada, mas que pouco lucravam com o seu trabalho, já que outros por eles lhes tabelavam os preços dos produtos e coarctavam os ganhos. E com estes se cruzavam tantos outros vizinhos das cidades e vilas, dos pequenos comerciantes e regatões aos obreiros e assalariados, que comungavam da mesma precária condição sócio-económica. A sua vida, já de si muito dura, ter-se-ia ainda mais ensombrado com as diversas e nefastas consequências de um prolongado estado de guerra. Como resposta, os artesãos e o povo amotinaram-se.

E fizeram-no, em grande parte, porque conheciam um vivido passado associativo. ${ }^{(35)}$ Foram os mesteirais gente trabalhadora que, desde cedo, conheceu a urgência de se unir em movimentos confraternais de solidariedades na vida e na morte. (36) Tantas vezes homens do campo, que se aventuravam a trabalhar na cida-

(33) Kurt Spang, Teoria del Drama. Lectura y análisis de la obra teatral, Pamplona, Ediciones Universidad de Navarra, S.A, 1991, p. 36.

(34) Esta temática desenvolveu Maria José Pimenta Ferro no estudo «A revolta dos mesteirais de 1383», in Actas das III Jornadas Arqueológicas 1977, Lisboa, Associação dos Arqueólogos Portugueses, 1978, pp. 359-383.

(35) Veja-se esta perspectiva social dos mesteirais em Maria Helena da Cruz Coelho, «O Povo - a identidade e a diferença no trabalho», in Portugal em Definição de Fronteiras. Do Condado Portucalense à Crise do século XIV, coord. de Maria Helena da Cruz Coelho e Armando Luís de Carvalho Homem, vol. III de Nova História de Portugal, dir. de Joel Serrão e A. H. de Oliveira Marques, Lisboa, Editorial Presença, 1996, pp. 278-284.

(36) Sobre a temática confraternal, em sentido amplo, leia-se Maria Helena da Cruz Coelho, «As confrarias medievais portuguesas: espaços de solidariedades na vida e na morte», in Confradias, gremios, solidaridades en la Europa Medieval. XIX Semana de Estudios Medievales, Estella 92, Estella, 1993, pp. 149-183. 
de, perdendo os seus protectores laços familiares de origem, homens sós e desenraizados da sua pequena pátria natal, sentiam a imperiosa necessidade de se agregarem em irmandades. ${ }^{(37)}$ À sombra da religião e pela força do associativismo, os oficiais de um idêntico mester, frequentemente vizinhos da mesma rua e fregueses da mesma igreja, resistiam assim unidos às possíveis tragédias da vida - uma catástrofe devida aos desequilíbrios dos elementos naturais, uma doença fortuita ou prolongada, uma invalidez pelo acaso infeliz de um acidente, ou a sombra dos difíceis anos da velhice. Em consentâneo, ganhavam a certeza de terem companheiros sufragantes na passagem desta vida para a do outro mundo, que thes sepultassem o corpo e alumiassem a alma, com círios, orações e missas, no temeroso caminho para o Além. Esta irmandade confraternal, que até nos actos mais extraordinários de peregrinação se manifestava, entretecia-se num corpo de autoridades próprias e em reuniões regulares dos confrades que, pelo menos uma vez ao ano, partilhavam entre si o pão espiritual na celebração eucarística e o pão, alimento do corpo, num vodo entre irmãos, que unia vivos e mortos, e se estendia caritativamente aos pobres e desprotegidos.

A fraternidade entre irmãos, caritativa, assistencial e sufragante, podia ainda ser reforçada por outros laços de assimilação. Assim era, no caso dos artesãos, com a vizinhança do habitar e laborar. Pelo menos já desde Undecentos, os mesteirais tenderam a ocupar, segundo a especificidade do seu mester, uma rua. Esse arruamento, voluntário e desejado, era ainda um meio de se defenderem e de buscarem a força da união para melhor resistirem. Iriam comunicando entre si e mesmo exercendo um controlo recíproco sobre os meios e modos de produção de que dispunham, a aquisição de matérias-primas e a qualidade dos artefactos, para além de oferecerem, de um modo acessível e cómodo, os produtos do seu labor à clientela.

Estes laços de união no trabalho e nas confrarias criariam um capital de associativismo que, em momentos excepcionais, podia tomar corpo em movimentos colectivos. Assim foi nas décadas de 70 e 80 do século XIV. Então a rua e as praças públicas eram os palcos dessa força associativa e os actores assumiam-se como a multidão dos que, dominados pelas oligarquias urbanas e senhoriais, erguiam a voz e praticavam actos, manifestando o seu protesto.

(37) Sobre estes associativismos dos oficiais mecânicos em terras de Castela, veja-se José Maria Monsalvo, "Solidaridades de oficio y estructuras de poder en las ciudades castellanas de la Meseta durante los siglos XIII al XV (aproximación al estudio del papel político del corporativismo artesanal)», sep. de «El Trabajo en la Historia», Séptimas Jornadas de Estudios Históricos organizadas por el Departamento de Historia Medieval, Moderna y Contemporánea de la Universidad de Salamanca, Salamanca, Ediciones Universidad, 1996, pp. 42-66; Maria Isabel del Val Valdivieso, «Elites urbanas en la Castilla del siglo XV (Oligarquía y Comum)», in Elites e redes clientelares na Idade Média. Problemas metodológicos, ed. de Filipe Themudo Barata, Lisboa, Edições Colibri-CIDEHUS-UE, 2001, pp. 80-83. 
O mote foi-lhes dado, nos inícios da década de 70, com o anúncio do casamento de $D$. Fernando com uma mulher que, segundo criam, desprestigiaria o seu rei e reino. Mas as raízes do descontentamento eram profundas, como dissemos, radicando na crise demográfica, económica e social que, desde a Peste Negra se instalara, e que as guerras com Castela, a deflação monetária e o tabelamento dos preços mais aprofundara.

O alfaiate Fernão Vasques lidera o movimento de oposição em Lisboa e as uniões repercutem em cadeia nas vilas de Santarém, Alenquer, Tomar e Abrantes. ${ }^{(38)}$ E depois prolongam-se de 1373 até finais do reinado do Formoso nestas mesmas vilas e noutras, como Leiria, Portel, Montemor-o-Velho e Sousel, como resposta à invasão castelhana na segunda guerra fernandina. Nelas se envolvem, entre outros, alfaiates, sapateiros, carpinteiros, correeiros e fanqueiros. ${ }^{(39)}$ Mas estes são só aqueles de que ficaram os nomes e profissão. Uns porque foram decepados, como o alfaiate Fernão Vasques, outros porque viram os seus bens confiscados. $\mathrm{O}$ todo era composto mais amplamente por gente do povo, esses «baraços cheos de lavradores e de mesteiraaes», ${ }^{(40)}$ com que D. Fernando compunha os exércitos e as armadas. Este recrutamento forçado dos homens de trabalho, a par dos demais males da guerra, provocava ódios, revoltas e uniões do povo, como também já de escudeiros, mercadores, ourives, tabeliães e escrivães, alargando o espectro social dos descontentes contra a política bélica do monarca e os seus malogrados tratos de pazes e acordos .

O clímax desses motins populares atinge-se depois da morte de D. Fernando. D. Beatriz, consorciada com D. João I de Castela, era para o povo a prefiguração do jugo castelhano, que já tanto os fizera sofrer. Então os homens, que só possuíam de seu o corpo para a labuta e nada tinham a perder, revoltam-se.

Logo, quando no palco dos mandantes do poder constituído se clama «arraial» por D. Beatriz, nos palcos dos mandados, os mesteirais e o povo miúdo assumem um poder pela força.

Em Lisboa reinou a perturbação, ninguém sabendo ao certo a quem aclamar em substituição de D. Beatriz e da temida submissão a Castela. ${ }^{(41)}$ Em Santarém, o alcaide pequeno convocou os «melhores do logar» para erguerem pendão e darem «arreal»

(38) Fernão Lopes, Crónica do Senhor Rei Dom Fernando Nono rei destes Regnos, introd. de Salvador Dias Arnaut, Porto, Livraria Civilização-Editora, 1966, caps. LX e LXI.

(39) Os mesteirais envolvidos ascendem a $46,6 \%$ como refere Maria José Pimenta Ferro, «art. cit.», p. 365, apresentando os seus nomes e profissões num quadro (p. 371). E, sobre o movimento de Sousel, leia-se Armando Luís de Carvalho Homem, «Nótula sobre um levantamento popular nas vésperas do Interregno», sep. Bracara Augusta, t. XXXII, fasc. 73-74 (85-86), Jan.-Dez. de 1978, pp. 3-19.

(40) Assim dizia a rainha que era composta a armada que atacou Sevilha na terceira guerra fernandina (Crónica do Senhor Rei Dom Fernando, cap. CXXVI).

(41) Crónica do Senhor Rei Dom Fernando, cap. CLXXV. 
por D. Beatriz. ${ }^{(42)}$ Correndo tais rumores, o povo juntava-se em «assuadas», opondo-se a que a vila alçasse pendão pelo rei de Castela. Havia grande confusão, ouvindo-se a voz do poder aclamando D. Beatriz e a do contra-poder anunciando o infante $D$. João, o filho da lembrada Inês. Mas nada se decide. Então faz-se ouvir um peliteiro, de nome Domingos Anes, "homem refeçe e de pequena comta», como diz Fernão Lopes, perguntando: «que estamos fazemdo, ou que pregom he este ?». E desembainhando uma espada galvaniza a multidão que persegue o alcaide até ao castelo e decididamente lança vivas por $\mathrm{D}$. João.

Também em Elvas o alcaide erguera a bandeira por D. Beatriz ao longo da vila. ${ }^{(43)}$ Um destemido escudeiro do lugar, sabendo disto ao regressar à vila, levantou uma bandeira por Portugal. $\mathrm{O}$ alcaide prendeu-o, mas perante tal acto, sem temor e desafrontadamente, afirmou Gil Fernandes: «leixaae vjinr aarraya meuda das vinhas, ca elles me tirarom daqui». E de facto, conhecida a prisão, repicaram os sinos, juntou-se a gente da vila com a que andava fora, e foram todos, mesmo mulheres e moços, combater o castelo, o que resultou na libertação do escudeiro e fuga do alcaide. Clara mobilização colectivaa ${ }^{(44)}$ dos que, nada tendo a perder, estavam sempre prontos, por alguma convicção ou mais ainda por anseios profundos de mudança e ânsia de melhores dias, a seguirem os mais audazes, esperando que da revolta nascessem «outros mundos».

Como não esperar dos conturbados acontecimentos que se seguiram, um tempo novo e uma crença num desejado Messias? ! (45)

Em Lisboa, no mosteiro de S. Domingos, o «comũu poboo livre e nom sogeito a algũus» pediu ao Mestre de Avis, que já ousara perpetrar, acompanhadamente a morte do Andeiro, que aceitasse ser Regedor e Defensor do Reino. ${ }^{(46)} \mathrm{E}$, perante o seu assentimento, prometeu-lhe a sua fidelidade até à morte. Mas este era o povo miúdo, que raramente decidia e comummente acatava. Na câmara deviam pronunciarse os «homrrados cidadãos», os detentores da autoridade e mando. Estes, porém, calavam. Falavam «mui manso» de orelha a orelha. Sopesavam, ponderavam, porque, como bem sabiam, as deliberações envolviam poder e riqueza. Desde logo dos próprios, para além dos da res publica. Acima da dúvida ergueu-se a voz do tanoeiro

(42) Crónica do Senhor Rei Dom Fernando, cap. CLXXVI.

(43) Crónica do Senhor Rei Dom Fernando, cap. CLXXVII.

(44) Esta mesma mobilização colectiva está presente noutras revoltas, em tempos da regência, como em Portalegre e Estremoz, em que homens e mulheres «tiinham bamdo pollo Meestre» (Cronica Del Rei Dom Joham I de Boa Memoria e dos Reis de Portugal o Decimo, Parte Primeira, prefácio de Luís F. Lindley Cintra, Lisboa, Imprensa Nacional-Casa da Moeda, 1977, cap. XLIII).

(45) Sobre esta temática, consulte-se Margarida Garcez Ventura, O Messias de Lisboa. Um estudo de Mitologia Política (1383-1415), Lisboa, Edições Cosmos, 1992.

(46) Cronica Del Rei Dom Joham ..., cap. XXVI. 
Afonso Anes Penedo, confrontando-os com o cenário da submissão a Castela.Tais razões não chegaram para convencer os maiores. Mas porque aquele tanoeiro só punha em causa a sua garganta, e desembainhou a espada para cortar a daqueles que o não seguissem, a razão da força e o alvoroço das gentes convenceram os honrados cidadãos a tomar o Mestre por Regedor e Defensor do Reino. E, mais uma vez, em pontuais momentos de alteração da ordem e da norma, os pequenos decidem pelos grandes. A rua vira palco do poder e os que sempre obedecem vêem-se obedecidos. Até porque a arraia miúda conhece poucos argumentos de retórica. Convence pela força dos seus actos e pela ousadia dos gestos de quem pouco ou nada tem a perder. E assim se prolongaram os episódios populares da tomada de muitos castelos pelo Mestre, ou da defesa esforçada de Lisboa aquando do cerco castelhano. Que não mais seguiremos.

Importa antes fazer balanços. Como recompensou o Mestre de Avis e, depois das Cortes de Coimbra de 1385, o rei D. João I o «poboo do Mexias de Lisboa»? (47)

Determinou, logo em Abril de 1384, que dois homens bons, letrados, estivessem no conselho do rei, representando o povo, e na câmara da cidade de Lisboa para darem, ou não, o seu acordo nos assuntos que lhes respeitassem. Estipulou que dois homens bons de cada mester integrassem a vereação lisboeta para deliberar sobre os nevrálgicos assuntos de posturas, lançamento de impostos e recolha ou arrendamento de taxas, sisas, talhas, fintas e serviços, e intervir nas eleições concelhias. Ratificou que os oficiais do concelho seriam eleitos e não de nomeação régia. Consentiu na isenção de aposentadorias e na submissão de todos, mesmo os privilegiados, ao pagamento de impostos, de acordo com a riqueza de cada um. Posteriormente, anuiu à isenção da almotaçaria, que sempre teria de ser ditada de acordo com os mesteirais. E esta mesma isenção de almotaçaria para mesteirais, braceiros e serviçais foi também outorgada a Évora. ${ }^{(48)}$

Claro favorecimento dos mesteirais, assalariados e povo comum. Medidas revolucionárias para um tempo revolucionário. Algo ameaçadoras da hierarquização social. Por isso efémeras. Os trabalhadores eram os pés da sociedade que a deviam sustentar com o seu labor. Eles eram os contribuintes e servidores dos concelhos e dos honrados cidadãos. Assim teriam de permanecer. Submetidos, não deliberantes.

Avançando os anos da governação joanina, a ordem será reposta. E, ao longo da centúria de Quatrocentos, o poder régio adensou-se em centralismo e burocracia, e

\footnotetext{
(47) Marcello Caetano, "O concelho de Lisboa na crise de 1383-1385», in A Crise Nacional de 1383-1385. Subsídios para o seu estudo, Lisboa-S. Paulo, Editorial Verbo, 1985, pp.129-134; Maria José Pimenta Ferro, «art. cit.», pp. 367-368.

(48) Gabriel Pereira, Documentos Históricos da Cidade de Évora, Primeira Parte, ed. fac-similada, Lisboa, Imprensa Nacional-Casa da Moeda, 1998, p. 84.
} 
o poder concelhio tornou-se mais oligárquico, restritivo e fechado. Para tal contribuiu mesmo decisivamente D. João I, com a lei dos pelouros de 1391, determinando que não mais as eleições dos oficiais concelhios fossem directas e públicas, mas se restringissem aos homens da vereação. Esses, em câmara, designariam os homens idóneos para juízes, vereadores, procuradores e chanceleres, que depois, anualmente, iam escolhendo. ${ }^{(49)}$ Elegíveis, eleitores e eleitos formavam um só grupo, o dos homens bons e honrados das cidades e vilas, que detinham o poder político. $\mathrm{Na}$ verdade, era essa elite dirigente que verdadeiramente servia a ideologia e política centralizadoras dos monarcas de Avis e os objectivos de um Estado de Guerra e de Finanças em que o reino se consubstanciava. ${ }^{(50)}$ Só este corpo restrito e oligárquico garantia a execução das ordens de recrutamento de homens e a cobrança de impostos para o reino. Logo, sempre e cada vez mais, como bem o demonstram as Ordenações Afonsinas, os monarcas visaram restringir o número dos eleitores e manter essa feição aristocrática da governação municipal. Depois, internamente, essas elites dirigentes reproduziam idênticos mecanismos de adscrição da gente ao trabaIho, nos seus bens pessoais ou nos serviços comuns dos lugares, e às exacções fiscais concelhias.

É certo que este corpo governativo, composto pelo patriciado de cada localidade, com tónicas díspares, mais de possidentes fundiários ou mais de mercadores e detentores de capital monetário, ainda que tantas vezes ambas as riquezas se caldeassem, tinha inimigos a vencer ou, pelo menos, a neutralizar. ${ }^{(51)}$

(49) Sobre esta lei, veja-se Maria Helena da Cruz Coelho e Joaquim Romero Magalhães, O Poder Concelhio..., pp. 18-19 e doc. IX.

(50) Uma visão desta ambiência de guerra através das Cortes encontra-se no estudo de Maria Helena da Cruz Coelho, "As Cortes e a Guerra», Revista de História da Sociedade e da Cultura, 1, Coimbra, Centro de História da Sociedade e da Cultura, 2001, pp. 61-80.

(51) Para uma análise da definição e composição social destas elites em vários países europeus, leia-se Philippe Braunstein, "Pour une histoire des élites urbaines: vocabulaire, réalités et représentations»; Alain Derville, «Les élites urbaines en Flandre et en Artois»; Philippe Jansen, «Élites urbaines, service de la commune et processus d'aristocratisation: le cas de Macerata aux XIVe-XVe siècles", in Les Élites Urbaines au Moyen Âge. XXVII Congrès de la Société des Historiens Médiévistes de l'Enseignement Supérieur Public, Paris, Publications de la Sorbonne, 1997, respectivamente, pp. 29-38, 119-200, 201-223; Fco. Javier Goicolea Julián, «Sociedade y poder Concejil. Una aproximación a la elite dirigente urbana de la Rioja Alta Medieval», Studia Historica, 17, Salamanca, 1999, pp. 87112. Para Portugal, consultem-se Maria Helena da Cruz Coelho e Joaquim Romero Magalhães, $O$ Poder Concelhio..., pp. 21-28 e Maria Helena da Cruz Coelho, «Les Élites Municipales», Anais - Série História, II, Lisboa, UAL, 1995, pp. 51-56; "O Estado e as Sociedades Urbanas», in A génese do Estado Moderno no Portugal tardo-medievo (séculos XIII-XV), coord. de Maria Helena da Cruz Coelho e Armando Luís de Carvalho Homem, Lisboa, UAL, 1999, pp. 269-292; «Elites de Trabalho e de Mando na Idade Média» (no prelo); Adelaide Lopes Pereira Millan da Costa, «Vereação»e «Vereadores». O governo do Porto em finais do século XV, Porto, Câmara Municipal do Porto, 1993 (sendo particularmente úteis as fichas biográficas dos oficiais); e «Prosopografia das elites concelhias e análise racional: a intersecção de duas abordagens», in Elites e Redes Clientelares na Idade Média..., pp. 63-70; Maria Ângela Rocha Beirante, Évora na Idade Média, Lisboa, FCG-JNICT, 1995, pp. 563- 
Desde logo, a autoridade régia, expressa em acto pelo seu oficialato, era incómoda e cerceadora de privilégios dos mandantes locais. Já algo se vai conhecendo, e sob variadas facetas, sobre a acção dos corregedores das comarcas, dos alcaides dos castelos ou dos juízes nomeados por el-rei, ainda que este nos pareça ser um cargo a requerer novas atenções.

Apenas gostaríamos de reter aqui os perigos que todos eles, e não menos a fidalguia, representavam, desde logo para a liberdade de escolha dos oficiais locais pelos homens da governança. Os procuradores às Cortes, que dão voz a esses mandantes, insurgem-se contra a ida daqueles às reuniões em que ocorriam as eleições. ${ }^{(52)}$ Como não menos clamavam contra a presença de tais oficiais e poderosos nas vereações, onde só a sua vontade, afeiçoada aos seus interesses, devia imperar. Repetiam-se as queixas, prova manifesta dessa interferência limitadora. ${ }^{(53)}$

Mas o monarca foi-se tornando mais presente num certo número de oficiais da sua nomeação. ${ }^{(54)}$ Ao longo de todo o século XV, os concelhos vão reclamando que os juízes dos órfãos, dos judeus, dos resíduos, das sisas e do vento e as suas escrivaninhas, a par da escrivaninha da câmara, deviam ser da livre escolha da vereação. ${ }^{(55)}$ Os monarcas não cedem, pelo que os municípios vão até matizando os seus agravos, pedindo por vezes já tão-só que os juízes ordinários pudessem controlar esses oficiais e eles fossem em número mais reduzido(56) ou que, por exemplo, os juízes dos órfãos não existissem em povoações até cem vizinhos, cabendo as suas funções aos juízes locais. ${ }^{(57)}$

-568 (tem as listas dos funcionários do concelho); Rita Costa Gomes, "As elites urbanas no final da Idade Média. Três pequenas cidades do interior», in Estudos e Ensaios de Homenagem a Vitorino Magalhães Godinho, Lisboa, Livraria Sá da Costa Editora, 1988, pp. 229-237; Miguel Gomes Martins, "A família Palhavã (1253-1357). Elementos para o estudo das elites dirigentes da Lisboa Medieval», Revista Portuguesa de História, t. XXXII, Coimbra, 1997-1998, pp. 35-93; "Estêvão Cibrães e João Esteves: A família Pão e Água em Lisboa (1269-1342)», Arqueologia e História, 53, Lisboa, Associação dos Arqueólogos Portugueses - Colibri, 2001, pp. 67-74; "Os Alvernazes. Um percurso familiar e institucional entre finais de Duzentos e inícios de Quatrocentos», Cadernos do Arquivo Municipal, 6, Lisboa, Câmara Municipal, 2002, pp. 10-43; Luís Miguel Duarte, "Os melhores da terra (um questionário para o caso português)», in Elites e Redes Clientelares..., pp. 91-106.

(52) A análise das matérias dos capítulos gerais baseia-se na obra de Armindo de Sousa, As Cortes Medievais Portuguesas (1385-1490), vol. II, Porto, INIC-CHUP, 1990, onde esses capítulos se encontram resumidos. Doravante referi-los-emos pelo local e data das Cortes, seguida do número de ordem do capítulo que aquele autor aponta em tal estudo. Neste caso, Coimbra, 1390 (2); Guimarães, 1401 (1); Leiria-Santarém, 1433 (48).

(53) Cortes de Santarém, 1451 (16), Lisboa, 1459 (19), Évora, 1460 (5), Santarém, 1468 (4), Coimbra-Évora, 1472-73 (162).

(54) Veja-se sobre o tema Amélia Aguiar Andrade, «Estado, Territórios e Administração Régia Periférica», in A Génese de Estado Moderno, pp. 151-187.

(55) Cortes de Viseu, 1391 (3); Lisboa, 1410 (26); Leiria-Santarém, 1433 (124); Lisboa, 1439 (22, 31); Coimbra-Évora, 1472-73 (148, 202); Évora, 1490 (35).

(56) Cortes de Santarém, 1430 (7); Évora-Viana, 1481-82 (126).

(57) Cortes de Santarém, 1468 (23). 
O judicial era disputado entre a coroa e o poder local, sendo particularmente cobiçadas por ambos as competências de decisão sobre impostos, testamentos, bens de menores ou judeus, matérias de vital importância social e económica. Assim também o controlo da memória sobre os actos. Os escrivães deste e de outros cargos, como ainda o da própria câmara, eram muitas vezes ofícios que dependiam do soberano, por uma nomeação expressa ou por um rogo, para que os mesmos fossem exercidos por seus apaniguados, devidamente indigitados. Para além de este ser um meio dos monarcas compensarem serviços e fidelidades de vassalos e criados, era também uma manobra hábil para controlar a acção dos dirigentes locais. Registadas as deliberações por escrito, elas transmutavam-se em memória codificada, que a qualquer momento podia ser relembrada e veiculada até aos destinatários que a desejassem conhecer. Bem evidente é, pois, o temor e oposição das oligarquias municipais face aos oficiais régios detentores do poder da escrita e conhecimento dos escritos, quando requeriam, nas Cortes de Coimbra de 1390 (10), que os tabeliães que exercessem funções concelhias não as acumulassem com o tabelionado, ou, avançando mais, nas Cortes de Évora de 1408 (14), pedissem mesmo que lhes fosse interdito o desempenho de cargos municipais.

Este oficialato régio de actuação local, com competências judiciais e burocráticas, a que se juntava também o de âmbito militar, alcaides, coudéis e anadéis, ou de alcance fiscal, como contadores e almoxarifes, era, sem dúvida, um corpo outro de agentes municipais que interferiam no poder e mando das elites locais. É certo, como já começa a ser esboçado, que os dois grupos podiam interligar-se e ser mesmo interrecorrentes, havendo homens com carreiras quer no poder central, quer no poder local, ${ }^{(58)}$ da mesma forma que os conluios e jogos de aliança entre o oficialato régio e concelhio tinham forçosamente de se desenvolver, podendo servir ambas as partes. (59)

No entanto, a nebulosidade ou indiferenciação das esferas de poder dos oficiais régios com actuação local não seria benéfica para os honrados cidadãos. Por isso pedem em Cortes que não haja acumulação de ofícios régios e concelhios, clarificação que os soberanos também parecem defender. ${ }^{(60)}$ Como não era desejável a sobreposição entre o oficialato eclesiástico e o municipal, (61) nem tão pouco a to-

(58) Maria Helena da Cruz Coelho, «O Estado e as Sociedades urbanas», pp. 288-289.

(59) Leia-se a este propósito Maria da Conceição Falcão Ferreira, Gerir e julgar em Guimarães no século XV. Subsídios para o estudo dos ofícios públicos, Braga, Arquivo Municipal Alfredo PimentaCâmara Municipal de Guimarães, 1993; «Relações entre poder local e poder central: aspectos de uma relação complexa», in Actas do Colóquio Internacional «Universo Urbanistico Português. 14151822», Lisboa, CPCDP, 2001, pp. 69-78.

(60) Cortes de Leiria-Santarém, 1433 (22); Lisboa, 1439 (46); Lisboa, 1455 (17).

(61) Cortes de Lisboa, 1439 (25). 
mada do poder por parte de acostados dos nobres, ${ }^{(62)}$ o que de novo a Coroa corrobora.

Nesta linha de interrecorrências, uma reflexão nos ocorre sobre certos capítulos gerais de Cortes quanto aos juízes de fora.

É bem conhecida a oposição imediata dos concelhos, aquando da nomeação mais frequente destes oficiais por D. Afonso IV. ${ }^{(63)}$ Do mesmo modo, é sabido que os monarcas, de acordo com a suas maiores ou menores urgências de um efectivo controlo e garantia de fidelidade de uma cidade ou vila, assim os foram nomeando ou repondo a justiça nas mãos dos cidadãos. Dentro desta linha de pensamento, percebe-se bem que os concelhos, nas Cortes de Coimbra de 1400 (1), estejam a pedir a sua extinção, ao que D. João I, governando já sobre todos os súbditos e terras do seu reino, aquiesce.

Mas em Cortes posteriores, podemos entrever outras subtilezas. Nas de Leiria de 1433 (13), ao discutir-se a responsabilidade do encargo do salário dos juízes por el-rei, propõe-se que os magistrados nomeados de motu proprio pelo soberano por ele fossem pagos; os que tivessem sido colocados a requerimento dos concelhos, destes receberiam os salários; e os que houvessem sido nomeados a rogo ou por causa de fidalgos e poderosos seriam tais privilegiados a suportar o seu vencimento. Mais esclarecidos ficamos ainda por capítulos apresentados às Cortes de Santarém de 1451(4) e de Évora-Viana de 1481-1482 (37). Os municípios rogavam que os monarcas só nomeassem juízes de fora quando os concelhos lho requeressem, o que poderia acontecer em conjunturas excepcionais, mormente de revoltas. Então esses magistrados deviam ser «entendidos e de boa consciência» para que impusessem a justiça. Mas, atente-se, o soberano só devia atender os pedidos para a nomeação de tal magistratura, por parte de quem fosse portador de uma carta assinada pelos oficiais do respectivo concelho e validada com o selo municipal.

Torna-se evidente que, em alguns concelhos e em certos momentos, os homens bons não conseguiam manter a justiça e a ordem. ${ }^{(64)}$ Apoiavam-se então num poder judicial outro que as impusesse, abdicando do seu privilégio maior de justiça própria, já que a paz seria mais importante que um estado de tumulto. Mas percebe-se também que, por dentro do patriciado local, reinavam facções. Que se podiam adiantar à vontade da maioria no pedido desse juiz de fora ao monarca, manobra que o corpo governativo pretende, de igual modo, neutralizar. Logo, face à presença de um juiz

(62) Cortes de Évora-Viana de 1481-82 (10).

(63) Maria Helena da Cruz Coelho, Joaquim Romero Magalhães, O Poder Concelhio..., pp. 12-14.

(64) Aliás, nas Cortes de Coimbra de 1385 (19), estavam justamente a pedir que pudessem degradar e confiscar os bens dos cabecilhas e membros de bandos armados. 
de fora num determinado concelho haverá que sopesar a vontade de quem o impôs - rei ou concelho - e os motivos que desencadearam a sua nomeação. E entre estes não serão dos menores as rivalidades entre a «sanior pars» dos «maiores» e o seu todo, potenciadoras de conflitos. Se o grupo das elites do poder se tendeu a restringir e fechar, haveria sempre quem aí quisesse aceder. As conjunturas, os acontecimentos, os diversos mecanismos económicos, os meandros da capilaridade social, fariam ascender alguns homens à riqueza e prestígio. Esses desejariam depois romper com o tradicional círculo dos detentores do poder, que já em boa parte era familiarmente transmissivel. ${ }^{(65)}$

Só um denso estudo das sociedades urbanas medievais nos permitirá mergulhar com profundidade nesta análise. Poderemos, todavia, percepcionar algumas vertentes desta problemática através dos agravos apresentados no areópago das Cortes. Assim, nas de Leiria-Santarém de 1433 (34), pedia-se que pudessem ser escolhidos para oficiais concelhios homens que não detivessem cavalo, abolindo-se a legislação em contrário, mas que não fossem vassalos del-rei. Já para juízes se requeria alguma habilitação literária, pois havendo nos concelhos homens que soubessem ler e escrever, não devia entregar-se a magistratura a analfabetos. ${ }^{(66)}$ Finalmente, nas Cortes de Évora-Viana de 1481-82 (160), rogava-se que fossem elegíveis para os cargos concelhios, não apenas os que moravam nas alcáçovas, como era comum, mas também os que habitavam nos arrabaldes.

Expressas ficam aqui algumas clivagens que atravessavam o círculo dos homens do poder - do velho privilégio, sem dúvida assente na fortuna, da cavalaria ser condição imprescindível para o desempenho de cargos concelhios e da detenção de saber, que cada vez mais se traduzia num capital técnico e especializado, até à diversificação dos suportes económicos e valores sociais que projectavam os que, na «baixa» das cidades e vilas, se entregavam a actividades comerciais e lucrativas e afirmavam a sua individualidade numa morada sita nessa tessitura urbana dos arrabaldes, sempre a refazer-se, vasada numa mentalidade mercantil e aberta à aculturação de gentes e ideias.

Estas específicas molduras sociais terão exigido readaptações e equilíbrios, ainda que por certo sempre instáveis, entre o grupo dos poderosos. A entrada nos meandros da governança através de uma aprendizagem pelo recrutamento por substituição de um oficial eleito, ou mediante um tirocínio pelos ofícios iniciais de procurador e vereador até ascenderem a juízes, seriam meios de ir incorporando este

(65) Para contextos europeus leia-se o interessante estudo de Elisabeth Crouzet-Pavan, "Les élites urbaines: apperçus problématiques (France, Angleterre, Italie)», in Les Élites Urbaines...pp. 9-28.

(66) Cortes de Leiria-Santarém, 1433 (56). 
homens novos. ${ }^{(67)}$ Imperioso se tornava que esses recém-chegados respeitassem o ordenamento estatuído. E, de facto, nas Cortes de Santarém de 1418 (4), os conceIhos reclamavam que, nas eleições, os pelouros dos candidatos a juízes, vereadores e procuradores fossem colocados separadamente para que quem «merece ser juiz (não) saia por procurador». A hierarquização funcional havia que ser respeitada. Logo, pior que a renovação, seria a subversão.

Dominadas as facções e reequilibradas as forças, os homens bons exercitaram o poder a seu contento. Controlaram os circuitos económicos das suas cidades e vilas; codificaram a sociedade local nos seus estamentos, valores e comportamentos; apropriaram-se dos circuitos enquadradores, assistenciais e caritativos.

Bateram-se junto dos monarcas para que os provedores e juízes dos hospitais e albergarias fossem nomeados pelos juízes e homens bons dos lugares e para que as autoridades concelhias controlassem as contas e administração das instituições assistenciais. ${ }^{(68)} \mathrm{E}$ assim tais cargos acabavam, muitas vezes, por ser exercidos pelos homens bons, embora estes sofressem, também aqui, a concorrência dos validos régios. ${ }^{(69)}$ Pugnaram por uma mendicidade legalizada e supervisada, que não encobrisse marginais e vadios. Rogaram e obtiveram a faculdade de os pobres só pedirem esmola mediante um atestado de invalidez, passado pelos juízes do lugar.(70)

Investiram em pedidos renovados aos monarcas, no geral aprovados sob condições, no sentido de disporem desse bem maior que era a disponibilidade de recrutamento de mão-de-obra em tempos em que esta escasseava. Queriam que os moços de soldada trabalhassem pelos salários estabelecidos e não servissem outros homens senão os bons dos lugares. Para evitar concorrências, reclamavam que os monarcas estabelecessem um salário máximo e punissem todos aqueles que o ultrapassassem. Neste contexto, os órfãos eram riqueza disputada. Visavam pois os oficiais concelhios apropriar-se do cargo de juiz dos órfãos, para depois compelirem estes menores ao trabalho rural e doméstico, nas vilas e lugares a que pertenciam, desviando-os dos mesteres, como seria talvez o seu maior desejo.

Aliás, o trabalho da terra, pela urgência do abastecimento urbano, encontrava-se na primeira linha das preocupações dos dirigentes concelhios. Não poucas vezes formularam pedidos em Cortes, que favoreciam a vida dos lavradores, rogando que não Ihes fossem tomados bens, serviços ou filhos à força, que não sofressem aposen-

(67) Sobre esta matéria consulte-se Adelaide Lopes Pereira Millan da Costa, «Vereação» e «Vereadores». pp. 71-95.

(68) Cortes de Évora, 1390-91 (8); Santarém, 1418 (39); Lisboa; 1455 (28).

(69) Cortes de Évora-Viana, 1481-82 (133).

(70) Cortes de Santarém de 1418 (23); Lisboa, 1427 (27). 
tadorias, que não servissem na guerra. Mas, em contrapartida, exigiam que os filhos dos lavradores seguissem a profissão dos pais, garantindo a reprodução desse corpo produtivo, que não devia ser desviado do amanho da terra. Por isso, tentavam negar aos lavradores a arrematação de rendas, a regatia ou a criação de gado. Lavrar a terra, semear e colher os frutos seriam as suas únicas missões. Outros, lucrando por eles, os cidadãos, colocariam no mercado, a bons preços, os géneros agrícolas. Como não menos se locupletariam como intermediários entre os maiores possidentes e os camponeses, ou como rendeiros das rendas.

Ainda mais duramente atingiram os mesteirais, no económico e social. ${ }^{(71)}$ Os assomos de protagonismo e acção e as recompensas obtidas pelos oficiais mecânicos em finais de Trezentos diluiram-se, em grande parte, na centúria seguinte.

Os concelhos reclamavam liberdade para elaborar posturas e ordenações sobre os seus salários, ao que D. João I acedeu logo nas Cortes de Lisboa de 1398 (2). Ao mesmo tempo, os grandes obtiveram a faculdade de tabelar o preço dos seus produtos, tendo conseguido, nas Cortes de Santarém de 1418 (26), que fossem abolidas as almotaçarias gerais, prevalecendo as locais.

Entretanto, se por um lado queriam adscrever os filhos dos mesteirais às profissões dos pais, garantindo a continuidade dos ofícios, era tantas vezes à custa deste estrato que mandavam ser recrutados os homens para o serviço régio, como não admitiam que fossem desviados lavradores ou outras forças laborais, como a dos órfãos, para o trabalho oficinal. ${ }^{(72)}$

Mas todas estas medidas, numa leitura outra, mostram a pujança do nosso artesanato que, se nunca terá avultado em circuitos internacionais, tinha de viabilizar o mercado interno. Na realidade, como bem sabemos, sempre que um ofício rareava num qualquer centro urbano, os concelhos dispunham-se a privilegiar os seus mestres, isentando-os, entre outros favores, de serviços e contribuições municipais, para os atrair ao lugar. ${ }^{(73)}$ Acresce que no burgo portuense, melhor conhecido pela abundância dos seus livros de vereação, ao percorrermos os róis dos homens da câmara, encontramos muitas vezes presentes, mais ou menos esporadicamente, em maior ou menor número, praticamente todos os oficiais mecânicos. Que aí estavam, é certo, individualmente, como marca da sua singular projecção económica ou social ou da

\footnotetext{
(71) Sobre estes mesmos aspectos vividos em Castela, veja-se o já citado estudo de José Maria Monsalvo, «Solidaridades de oficio», pp. 66-90.

(72) Cortes de Lisboa, 1439 (8); Évora-Viana, 1481-82 (131); Coimbra 1391 (11); Leiria-Santarém, 1433 (21); Évora, 1490 (29).

(73) Uma síntese sobre estes privilégios colhe-se em Henrique da Gama Barros, Historia da

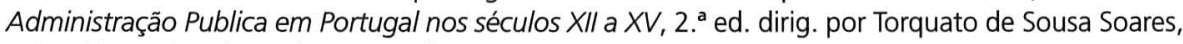
t. IX, Lisboa, Livraria Sá da Costa-Editora, 1950, pp. 299-310.
} 
sua particular afeição e serviço às elites. ${ }^{(74)}$ Mas pouco mais fazendo que presenciar esse «grande teatro do mundo» que eram as reuniões camarárias. ${ }^{(75)}$

Algumas vezes, porém, eram requisitados mais em colectivo, quando se tinha em vista tomar deliberações sobre a sua profissão. Recorrentemente, os carniceiros foram chamados à câmara, porque o abastecimento de carne era sempre escasso e os preços altos, sendo necessário negociar com estes fornecedores para servir o bem comum. ${ }^{(76)}$ Igualmente foram chamados os sapateiros para se firmarem acordos sobre o fornecimento e preçário da «calçadura».(77)

Noutros casos, os mesteirais eram excepcionalmente convocados para ouvir ler cartas de reis, rainhas e infantes, determinando ordens que seria necessário cumprir, ou para obter a mobilização dos vizinhos, como no caso da defesa do privilégio portuense de não abrigar fidalgos no interior do burgo, ou ainda para anunciar a realização de festividades que a câmara se propunha levar a efeito e que seriam, em grande parte, os trabalhadores a suportar em despesas e serviços. ${ }^{(78)}$ Tal como eram os mesteirais que serviam em certos ofícios executivos de vigilância, como os de quadrilheiros ou os de ouvidores e meirinhos dos termos.

Mais amplamente, e no seguimento dos privilégios obtidos em Lisboa, os mesteirais, em representatividade dos seus mesteres, foram sendo admitidos às câmaras, ainda que em números e com poderes diversos, para deliberar ou votar sobre os assuntos que Ihes diziam respeito. Assim aconteceu no Porto em 1392, em Santarém em 1436, em Tavira em 1446, em Évora em 1459. ${ }^{(79)}$ Foi precisamente este

(74) Solução que se apresenta em Castela face à denodada oposição das oligarquias contra o acesso ao poder dos representantes do «comum», como o demonstra Maria Isabel de Val Valdivieso, «Elites urbanas en la Castilla del siglo XV (Oligarquía y Comum)», in Elites e redes clientelares na Idade Média, pp. 84-86.

(75) José Antonio Jara Fuente, «Sobre el concejo cerrado. Asamblearismo y participación política en las ciudades castellanas de la Baja Edad Media (Conflictos inter o intra-clase)», Studia Historica, vol. 17, 1999, p.120.

(76) «Vereaçoens». Anos de 1390-1395, vol. II de Documentos e Memórias para a História do Porto, comentário e notas de A. de Magalhães Basto, Porto, Câmara Municipal, s.d., pp. 189-191, sessão de 18 de Abril de 1393; «Vereaçoens». Livro I, 1431-1432, vol. XLIV de Documentos e Memórias para a História do Porto, leitura, índices de notas de João Alberto Machado e Luís Miguel Duarte, Porto, Arquivo Histórico, Câmara Municipal, 1985., pp. 126-128, sessão de 21 de Junho de 1432.

(77) «Vereaçoens». Anos de 1401-1449, vol. XL de Documentos e Memórias para a História do Porto, com nota prévia de J. A Pinto Ferreira, Porto, Câmara Municipal, 1980, pp.13-14, sessão de 2 de Julho de 1401; pp. 28-29, sessão de 16 de Julho de 1401; pp. 449-454, sessão de 14 de Maio de 1441 ; pp. 321-325, sessão de 7 de Agosto de 1440.

(78) A título de exemplo, «Vereaçoens». Anos de 1401-1449, pp. 380-382, sessão de Dezembro de 1440 ,

(79) A. H. de Oliveira Marques, Portugal na Crise dos Séculos XIV e XV, vol. IV de Nova História de Portugal, dir. de Joel Serrão e A. H. de Oliveira Marques, Lisboa, Editorial Presença, 1987, pp. 201202. Aí se refere que no Porto os mesteirais participavam nas reuniōes camarárias, em 1392 sem voto, e a partir de 1475 com direito a voto. 
papel político, mesmo que escasso, que as elites urbanas porfiaram em negar-lhes. Com um profundo desdém, nas Cortes de Évora-Viana de 1481-82, os «grandes», os «nobres», os «senhores», "OS «sabedores», os «maiores», os «boons amtigos cidadaãos» ergueram a voz para repudiar os «plebeus», os de «baixa mãao», os «meeeãos e...os mais baxos», os «inferiores», os «populares», os «prebeos dos mesteres». (80) Abonaram-se na ciência política aristotélica e bartoloniana e, entre muitos argumentos aduzidos para exigirem que os mesteres nunca estivessem nas câmaras, chegaram a afirmar, depreciativamente, "ca he conhecida cousa que os popullares nom conhecem que cousa he policia nem sabem que cousa he honra nem quamdo deve a homrra preceder o proveito nem podem distinguir amtre as virtudes moraees soomẽe como homẽes atonitos cum tumultos e vozes vãas dam clamores de ora escolherem e ora imgeitarem ». ${ }^{(81)}$ Mas o monarca não negará voz aos oficiais mecânicos em Lisboa.

Insistem de novo os homens da governança nas Cortes de Évora de 1490. Desejam ver os mesteirais afastados dos ofícios régios e concelhios e do tabelionado, como já no anterior parlamento haviam rogado que eles não administrassem estalagens. Mais determinadamente pugnam para que os mesteirais não estivessem na câmara de Lisboa e, se de todo não fosse possível afastá-los, que aí se mantivessem como «olheiros» e sem direito a «dar voz», pedido que o monarca adia para ulterior decisão.

Face a este ostracismo a que os remetem os homens do poder, os «meãos» estão em profunda união com os «mais baixos». E se não se lhes oferecem, com frequência, ocasiões de revolta, é sempre possível ir resistindo e contestando. A nível local ou mesmo nacional. Buscam então expressar as suas reivindicações, ao mais alto nível, junto do monarca e dos oficiais régios. Se os concelhos, através dos seus procuradores, sempre tiveram ensejo, a partir de meados de Duzentos, de expressar os seus agravos em Cortes, tais procuradores, já o sabemos bem, eram, em grande parte, porta-vozes das elites governativas. Raramente apresentavam as «dores» dos outros dos que trabalhavam, serviam e pagavam. Souberam estes, porém, mobilizar-se. Apelando à sua identidade laboral e social, fizeram chegar a algumas Cortes delegações paralelas às oficiais. Em alguns casos não terão atingido sequer o palco maior do parlamento, ficando-se apenas pelos seus bastidores. Seriam tão-só ouvidos pelos oficiais régios. Mas estes, em nome do rei, decidiam sobre os agravos expostos e era

(80) Leia-se este capítulo de Cortes em Maria Helena da Cruz Coelho e Joaquim Romero Magalhães, O Poder Concelhio..., doc. XI. O discurso social, bem como a intitulação das elites, serão indicadores importantes para averiguar a honorabilidade e notabilidade dos seus membros, bem como a evolução dos conceitos, como o demonstra Thierry Dutour, no estudo «La supériorité sociale à Dijon à la fin du Moyen Âge (XIIIe-XIVe - début XVe siècles)», in Les élites Urbaines..., pp. 305-317.

(81) Maria Helena da Cruz Coelho, Joaquim Romero Magalhães, O Poder Concelhio, doc. XI. 
isso que importava. Sobretudo se, como aconteceu na maioria dos casos, Ihes dessem razão.

Apresentaram-se assim, por ocasião dessas grandes assembleias deliberativas, os mesteres, o povo miúdo, os pequenos das cidades e vilas ou os moradores e lavradores do termo de Ponte de Lima, Porto, Guarda, Coimbra, Santarém, Torres Novas, Estremoz e Évora através de procuradores que por eles falavam. ${ }^{82)}$ O que pressupõe, desde logo, a existência de líderes capazes de reunir assembleias e auscultar vontades, sabendo depois canalizá-las até aos meandros burocráticos do poder supremo. E tais delegações são, desde logo, a expressão clara da dominância da sede mais urbanizada dos concelhos sobre o seu termo, essencialmente rural e, no interior dos centros urbanos, a expressão da dicotomia entre os que dirigem a política e a economia e os que trabalham e são afastados das deliberações. Não pormenorizaremos aqui todas as suas reivindicações, que remetemos para um estudo aprofundado que temos em mãos. Como nota comum, é de realçar que agora estamos perante o negativo do registo das delegações oficiais. Escutam-se severas críticas contra as oligarquias locais. Conhecem-se os seus artifícios de poder e mando, os seus conluios, a sua actuação opressiva. A que se somam também veementes queixas contra a fiscalidade régia, abusiva e discriminadora, a que os mandantes fechavam os olhos, porque as suas extorsões atingiam sobremaneira os estratos produtivos e muito em especial os do campo.

Sublinhemos, porém, alguns recortes.

Coimbra mobilizou um caçador-mor do rei como representante dos moradores do termo, certamente pelas identidades da ambiência rural que ambos partilhavam, para estar presente nas Cortes de 1459. Mas se este expressa queixas dos lavradores do termo da cidade e dos moradores do couto de Semide contra a acção dos cobradores régios, não deixa igualmente de pedir que Coimbra tivesse o mesmo regimento de Lisboa e Santarém quanto aos mesteres. Reclamavam, pois, a sua presença em vereação, acrescentando «e saberemos as cousas como andam e os dinheiros do concelho como se despendem», para além de assim «procurarem» pelos lavradores. ${ }^{(83)}$ É a manifestação da solidariedade urgente entre os que, sempre mandados, querem pelo menos vigiar esse mando e ter voz para expor os seus males. Porque se os mesteirais poderão representar entre nós a «elite do povo comum» ${ }_{r}^{(84)}$ não nos

(82) Sobre o sentido destas delegações paralelas leia-se o que escreveu Armindo de Sousa, As Cortes Medievais, vol. I, pp. 210-214.

(83) $\pi$ - Estremadura, liv. 7, fls. 245v-246.

(84) Muito significativo sobre a definição e actuação das elites políticas e das elites do «comum» para Castela é o estudo de Maria Isabel del Val Valdivieso, "Elites urbanas en la Castilla del siglo XV (Oligarquía y Comum)», in Elites e redes clientelares na Idade Média, pp. 71-89. 
parece que tenha havido grandes clivagens entre eles e o conjunto do povo, até porque as elites políticas pretendiam igualá-los e subjugá-los do mesmo modo.

Por sua vez os «pequenos» de Ponte de Lima sabem desmontar perfeitamente os vícios das estruturas dirigentes. Os «maiores» da vila são todos entre si irmãos, tios, primos e cunhados, pelo que os pelouros dos ofícios «nunca lhes saem da mão». (85) E isto sem embargo de na vila e termo haver outras pessoas, fidalgos e escudeiros, muito pertencentes para os ofícios e que até por vezes já haviam sido juízes. Mas, e estamos em 1459, o círculo do poder restringira-se. Porque só assim, quase «em família», diríamos, é que esses poderosos lançavam grossas peitas e exigiam serviços dos homens para as suas vinhas, onde traziam mais de cem homens. Clamam então os agravados: "e todo esto he estraguo da terra e em espicial de nós outros hos pequenos». Mais acrescentam que tais governantes consideram «que nós pees hos avemos de servir e adorar e se o asi nom fazemos loguo nos ameaçam e nos levam mayores talhas que aos outros que os servem e nos fazem servir com pressos e nas outras serventias do concelho tres vezes dobrado». Ora, como rematam: «todo esto cessaria se os ditos officiaaes amdassem per muitas pessoas pois que os hii ha». 0 povo comum tem, pois, a clara noção do sentido opressivo de um poder oligárquico, pedindo concretamente que, pelo menos, exista um juiz da vila e outro do termo para contrabalançar interesses e vontades. Se os plebeus não conheciam a doutrina de Aristóteles ou Bártolo, analisavam perfeitamente a política dos dirigentes locais.

Aqui rogava-se por equilíbrios internos. Já os procuradores dos mesteres do concelho de Santarém visavam um controlo externo. Queriam que o corregedor se demorasse na vila «porque elle exucuta milhor as hordenaçooes e pusturas do concelho que os offyciaaes della e da milhor hordem e maneyra e repairo aos officyaaes e esso mesmo toma as comtas mais sem afeiçooees e exucuta milhor as dividas que elles...».(86) Os oficiais não pretendiam tê-lo por perto mais de quinze dias, enquanto os mesteirais rogavam que ele se demorasse dois meses e mais, se fosse necessário. Era a certeza de um poder superior ao dos governantes a zelar pelo bem comum, punindo as «affeições» dos grandes que «escusam quem lhes apraz» e igualando no cumprimento das ordenações tanto "o grande como o pequeno».

Não nos alongaremos mais neste enumerar de denúncias sobre os desmandos dos actores do poder constituído. E também por aqui nos quedaremos na encenação da teatralidade do poder municipal no seu todo.

\footnotetext{
(85) TT - Além Douro, liv. 3, fls. 31v-32.

(86) $\pi$ - Estremadura, liv 7, fls. 268-269.
} 
O reino de Portugal, nos séculos XIV e XV, conheceu um poder concelhio activo e actuante. Sujeito, porém, a regras, comportamentos e actuações específicas.

A Coroa apoiava-se nestes poderes locais de concelhos e senhorios para dominar burocrática e administrativamente territórios e homens. Mas procurava controlar esses poderes e concertá-los com as suas linhas de acção política. Conseguiu que os municípios fossem cadeias da sua máquina de guerra e de fisco. Não logrou que os mesmos se integrassem nos circuitos de livre circulação e transacção de mercadorias. Porque esses centros sempre umbilicalmente cuidavam dos seus interesses próprios, descurando os alheios e gerais.

Por sua vez, o exercício do poder municipal foi-se afastando dos muitos actores e das amplas assembleias deliberativas, para se confinar ao espaço fechado de uma câmara e a uma minoria de oficiais e homens bons. A política régia e a conjuntura de Quatrocentos favoreceu inequivocamente essa feição restrita, oligárquica e fechada do poder local.

Todavia, no senhorio colectivo que era um concelho, o poder dos eleitos dimanava de todos os que nele moravam e o sustentavam. Conceito teórico que a prática cada vez mais contrariava. Mas suficientemente enraizado para que os vizinhos, sentindo-se lesados, reagissem. Não se sublevavam contra a trifuncionalidade sócio-política vigente, aceitando «que os maiores na Repubrica devem reger e governar e os meeãos obedecer e ajudar e os mais baxos trabalhar e servir». ${ }^{(87)}$ Esses meãos e baixos reservavam-se, porém, o direito de lutar pelos seus interesses e vigiar os maiores.

A sua força advinha-lhes de uma forte igualdade de vida, sujeita a similares condições de trabalho, de serviço e contribuições. Acrescida de linhas de solidariedade horizontal e de laços associativos que estes homens mais desprotegidos e carentes sempre buscaram e reforçaram. E assim, em certas conjunturas especiais, essas uniões exprimiram-se em movimentos colectivos. O submisso povo miúdo subverteu. De público passou a actor e dirigiu a cena política. Momentos excepcionais. Habitualmente os dominados sujeitavam-se, mas resistiam na demora do cumprimento de ordens ou mesmo na contestação do mando. Como o fizeram nas delegações paralelas às Cortes, apontando o dedo aos governantes, revelando as suas manobras e excessos, reclamando justiça e reparação dos danos. Do êxito do seu agir só o tempo vivido, que não o contado, poderia oferecer a real dimensão.

Mas, inequivocamente, os municípios, mais ensombrada ou mais iluminadamente, cumpriram uma missão no Portugal da Monarquia e da República. Estrutruraram sociedades e poderes no Continente e no Império. Hoje, em democracia, mais deles

(87) Capítulo das Cortes de Évora-Viana de 1481-82, in Maria Helena da Cruz Coelho e Joaquim Romero Magalhães, O Poder Concelhio..., doc. XI. 
se espera. Porque é dentro deles que se devem gerar as forças vivas da cidadania, do associativismo e do comprometimento político, em tempos e espaços de Comunidades ou de um Mundo Global, que não pode e não deve dissolver identidades, gorar sonhos ou abater vontades. 
(Página deixada propositadamente em branco) 
Investigaçāo

Coimbra.

Imprensa da Universidade 